\title{
IMPLEMENTASI KEPUTUSAN GUBERNUR KEPALA DAERAH TINGKAT I BALI NOMOR 394 TAHUN 1997 DALAM MEMBERIKAN PERLINDUNGAN HUKUM BAGI SEKAA/ ORGANISASI KESENIAN
}

I MADE BADRA

Program Magister Ilmu Hukum Universitas Udayana

\begin{abstract}
In order to create order and legal certainty to the type and quality of local arts to tourism, the Government of Bali Province issued the Regional Decision of The Governor of The Head of Bali Number 394 of 1997 on Regulating Regional Arts on The Province of Bali. Implementation of the Regional Decision of The Governor of The Head of Bali Number 394 of 1997 on Regulating Regional Arts on The Province of Bali of the terms, procedures and sanctions do not work effectively. These are caused because of legal substance, legal structure, legal culture and the means and facilities. To optimize the decision made by the Governor of the preventive and repressive efforts. To streamline the implementation of the Regional Decision of The Governor of The Head of Bali Number 394 of 1997 will require a synergy between the Department of Culture, sekaa / arts organizations and the service users. Regional Decision of The Governor of The Head of Bali Number 394 of 1997 should have to be amended because it does not fit with the times. Bali Provincial Cultural Office should be more proactive in doing preventive and repressive efforts in upholding the Regional Decision of The Governor of The Head of Bali Number 394 of 1997.
\end{abstract}

KEY WORDS: Decision of the Governor, the arts and sekaa.

\section{PENDAHULUAN}

Dalam rangka mewujudkan ketertiban dan kepastian hukum terhadap jenis dan mutu kesenian daerah untuk pariwisata, Pemerintah Provinsi Bali mengeluarkan Peraturan Daerah Nomor 3 Tahun 1991 tentang Pariwisata Budaya. Pengaturan pariwisata budaya yang meliputi penggunaan kebudayaan daerah Bali khususnya pengaturan jenis dan mutu kesenian daerah merupakan pola kebijakan Pemerintah Provinsi Bali. Kebijakan tersebut sebagaimana yang diatur dalam Pasal 9 ayat (2) Perda Nomor 3 Tahun 1991 yang menyebutkan : “Jenis-jenis dan mutu kesenian daerah untuk wisatawan dan tempat pertunjukannya ditetapkan dengan Keputusan Gubernur Kepala Daerah". Berdasarkan amanat Pasal 9 ayat (2) Perda Nomor 3 Tahun 1991 tersebut kemudian terbitlah Keputusan Gubernur Kepala Daerah Tingkat 
I Bali Nomor 394 Tahun 1997 tentang Pengaturan Kesenian Daerah di Propinsi Daerah Tingkat I Bali.

Secara substansial, hal-hal penting yang diatur dalam Keputusan Gubernur Nomor 394 Tahun 1997 adalah tentang ijin pertunjukan, jenis kesenian yang boleh dipertunjukkan dan yang tidak boleh dipertunjukkan, tentang pembinaan dan pengawasan. Keputusan Gubernur Kepala Daerah Tingkat I Bali Nomor 394 Tahun 1997 tentang Pengaturan Kesenian Daerah di Propinsi Daerah Tingkat I Bali, merupakan pedoman dalam bertindak terkait dengan pembinaan, pengembangan, pelestarian dan pengawasan kesenian daerah, sehingga mampu berdaya guna dan berhasil guna dalam mewujudkan cita-cita pariwisata untuk Bali.

Berdasarkan data yang diperoleh dari Dinas Kebudayaan Provinsi Bali dapat diketahui bahwa tingkat kesadaran hukum sekaa kesenian untuk mencari surat ijin seni pertunjukan masih rendah. Dari 166 jumlah sekaa/organisasi kesenian di Provinsi Bali yang terdaftar di Dinas Kebudayaan Provinsi Bali tercatat hanya 18 sekaa/organisasi kesenian yang memiliki surat ijin. Berdasarkan data pendahuluan di atas tampak adanya problem dalam pelaksanaan Keputusan Gubernur Kepala Daerah Tingkat I Bali Nomor 394 Tahun 1997. Terdapat kesenjangan antara apa yang diinginkan oleh Keputusan Gubernur tersebut (das sollen) dengan apa yang terjadi dalam kenyataan (das sein).

Dalam penelitian ini terdapat dua permasalahan yang akan dibahas lebih lanjut yaitu (1) faktor-faktor apakah yang mempengaruhi implementasi Keputusan Gubernur Kepala Daerah Tingkat I Bali Nomor 394 Tahun 1997? dan (2) apakah upaya-upaya Pemerintah Provinsi Bali untuk melindungi sekaa/ organisasi kesenian? Dengan demikian tujuan umum dalam penelitian ini adalah untuk mengetahui implementasi Keputusan Gubernur Bali Nomor 394 Tahun 1997 tentang Pengaturan Kesenian Daerah di Provinsi Daerah Tingkat I Bali. Tujuan khusus adalah untuk mengetahui faktor-faktor yang mempengaruhi implementasi Keputusan Gubernur Kepala Daerah Tingkat I Bali Nomor 394 Tahun 1997 dan upaya-upaya Pemerintah Provinsi Bali untuk untuk melindungi sekaa/ organisasi kesenian. 


\section{METODE PENELITIAN}

Bila dilihat dari jenis penelitian, penelitian ini menggunakan metode penelitian hukum empiris atau yang juga disebut penelitian dengan metode sosio legal research ${ }^{1}$ karena mengkaji bekerjanya Keputusan Gubernur Kepala Daerah Tingkat I Bali Nomor 394 Tahun 1997 dalam masyarakat, khususnya di lingkungan masyarakat sekaa kesenian. Penelitian ini bersifat deskriptif analitik. Di dalamnya terdapat upaya mendeskripsikan, mencatat, menganalisis dan menginterpretasikan kondisi-kondisi yang sekarang ini terjadi atau ada.

Jenis data yang dipergunakan dalam penelitian ini meliputi data primer dan data sekunder. Data primer yaitu data dasar yang diperoleh langsung dari para informan dan responden yang terkait dengan permasalahan yang diteliti yaitu Para Seniman (sekaa/ organisasi kesenian) dan Dinas Kebudayaan Provinsi Bali. Data sekunder diperoleh dari hasil penelitian kepustakaan (Library Research). Data sekunder berupa bahan-bahan hukum, baik bahan hukum primer maupun sekunder. ${ }^{2}$ Bahan hukum primer yang digunakan dalam penelitian ini adalah Undang-undang Nomor 9 Tahun 1990 tentang Kepariwisataan, Peraturan Daerah Provinsi Bali Nomor 3 Tahun 1991 Tentang Pariwisata Budaya dan Keputusan Gubernur Kepala Daerah Tingkat I Bali Nomor 394 Tahun 1997 tentang Pengaturan Kesenian Daerah di Propinsi Daerah Tingkat I Bali. Bahan-bahan hukum sekunder berupa semua publikasi tentang hukum baik dalam bentuk buku, jurnal maupun artikel ilmiah lainnya.

Pengolahan data sebagai tindakan pendahuluan dari analisis data, dilakukan dengan tahap editing. Pada tahap ini dilakukan pengecekan akan kelengkapan dari data yang telah terkumpul sehingga memudahkan pengolahan lebih lanjut. Data yang sudah ada diedit terkumpul diklasifikasikan atau dikatagorikan sesuai dengan permasalahan, selanjutnya dianalisis dengan mengkaitkan data yang satu dengan yang lainnya, ditafsirkan untuk memperoleh simpulan terhadap permasalahan yang diajukan. Keseluruhan hasil analisis kemudian disajikan secara diskriptif analitis

\footnotetext{
${ }^{1}$ Bambang Sunggono. 2009, Metodologi Penelitian Hukum. Jakarta: Rajawali Pers, h. 42.

${ }^{2}$ Soerjono Soekanto dan Sri Mamudji, 1986. Penelitian Hukum Normatif Suatu Tinjauan Singkat. Jakarta: CV. Rajawali, h. 14-15.
} 
yaitu dipaparkan secara lengkap segala persoalan terkait dengan permasalahan yang diteliti, setelah dikritisi disertai dengan ulasan-ulasan sesuai dengan teori-teori hukum.

\section{HASIL DAN PEMBAHASAN}

FAKTOR-FAKTOR YANG MEMPENGARUHI IMPLEMENTASI KEPUTUSAN GUBERNUR KEPALA DAERAH TINGKAT I BALI NOMOR 394 TAHUN 1997

Keputusan Gubernur Kepala Daerah Tingkat I Bali Nomor 394 Tahun 1997 tentang Pengaturan Kesenian Daerah Tingkat I Bali adalah suatu produk hukum yang dikeluarkan oleh Gubernur selaku kepala daerah provinsi. Dalam Keputusan Gubernur tersebut diatur beberapa hal yang substansial diantara mengenai surat ijin pertunjukan, ketentuan kesenian yang boleh dan tidak boleh dipertunjukkan, kewajiban sekaa dan kewajiban pengguna jasa. Keputusan Gubernur ini diharapkan dapat memberikan perubahan sosial dalam menilai pertunjukan kesenian. Dalam memberikan format atas hubungan interaksi perubahan sosial dan perubahan hukum adalah :

1. Hukum melayani kebutuhan masyarakat, agar supaya hukum itu tidak akan ketinggalan oleh karena lajunya perkembangan masyarakat.

2. Hukum dapat menciptakan perubahan sosial dalam masyarakat atau setidaktidaknya dapat memacu perubahan-perubahan yang berlangsung dalam masyarakat. $^{3}$

Keputusan Gubernur Kepala Daerah Tingkat I Bali Nomor 394 Tahun 1997 belum dilaksanakan dengan efektif. Faktor-faktor yang mempengaruhi efektivitas pelaksanaan Keputusan Gubernur Kepala Daerah Tingkat I Bali Nomor 394 Tahun 1997 dapat disederhanakan menjadi faktor substansi hukum, struktur hukum, budaya hukum dan sarana serta fasilitas dalam penegakan hukum.

Substansi hukum yaitu keseluruhan aturan hukum, norma hukum dan asas hukum, baik yang tertulis maupun tidak tertulis, termasuk putusan pengadilan. Secara umum substansi hukum yang mengatur mengenai upaya-upaya perlindungan terhadap tenaga kerja khususnya pekerja seni pertunjukan sudah cukup memadai.

${ }^{3}$ Saifullah. 2007, Refleksi Sosiologi Hukum, Bandung: PT Refika Aditama, h. 31. 
Namun permasalahan mendasar justru ada pada peraturan teknisnya. Perlindungan terhadap pekerja seni ini diatur dalam Keputusan Gubernur Kepala Daerah Tingkat I Bali Nomor 394 Tahun 1997. Pengaturan dalam bentuk surat Keputusan ini melemahkan pelaksanaan dari Keputusan Gubernur Kepala Daerah Tingkat I Bali Nomor 394 Tahun 1997 itu sendiri. Dalam Keputusan Gubernur tidak boleh memuat mengenai sanksi pidana. Sanksi pidana hanya dapat dicantukan dalam undangundang dan peraturan daerah.

Upaya untuk meningkatkan Keputusan Gubernur Kepala Daerah Tingkat I Bali Nomor 394 Tahun 1997 menjadi peraturan daerah pernah dilakukan. Hal ini terekam dari rapat yang diselenggarakan oleh Dinas Kebudayaan Provinsi Bali dengan beberapa instansi terkait pada 18 Desember 2001, namun upaya tersebut belum membuahkan hasil. Keputusan Gubernur Kepala Daerah Tingkat I Bali Nomor 394 Tahun 1997 hanya memuat sanksi administrasi bagi sekaa/ organisasi kesenian. Sanksi tersebut tercantum dalam Pasal 17 Keputusan Gubernur Kepala Daerah Tingkat I Bali Nomor 394 Tahun 1997 disebutkan:

(1) Ijin pertunjukan kesenian daerah ini dapat dicabut apabila:

a. tidak memenuhi ketentuan persyaratan penyelenggaraan pertunjukan kesenian daerah sebagaimana telah ditetapkan dalam Keputusan ini.

b. melakukan penyimpangan pengusahaan pertunjukan kesenian daerah.

c. melakukan pelanggaran atau penyimpangan kegiatan pertunjukan kesenian daerah yang telah mendapatkan persetujuan Gubernur Kepala Daerah.

(2) Penindakan terhadap sekaal organisasi kesenian yang melakukan penyimpangan dengan langkah-langkah sebagai berikut:

a. Peringatan lisan.

b. Peringatan tertulis.

c. Pencabutan ijin.

Sanksi hanya ditujukan pada sekaa / organisasi kesenian, sedangkan sanksi bagi pemakai jasa tidak diatur dalam Keputusan Gubernur Kepala Daerah Tingkat I Bali Nomor 394 Tahun 1997 padahal ada beberapa kewajiban hukum bagi pemakai jasa yang diatur dalam Keputusan Gubernur ini. Hal tersebut melemahkan penegakan terhadap Keputusan Gubernur Kepala Daerah Tingkat I Bali Nomor 394 Tahun 1997. Dilihat dari usia produk hukum ini, Keputusan Gubernur Kepala Daerah Tingkat I Bali Nomor 394 Tahun 1997 sudah sangat tua. Apalagi untuk ukuran suatu 
produk hukum yang bersifat sangat teknis. Substansi dari pasal-pasal mengenai pengupahan sudah tidak sesuai dengan perkembangan zaman apalagi setelah adanya krisis ekonomi global dan beberapa kali kenaikan bahan bakar minyak.

Perubahan upah sesungguhnya dapat dilakukan dan memang dimungkinkan sebagaimana yang tercantum dalam Pasal 12 ayat (2) dan (3) Keputusan Gubernur Kepala Daerah Tingkat I Bali Nomor 394 Tahun 1997. Dalam ayat (2) pasal tersebut diatur bahwa "Upah sebagaiman tersebut ayat (1) dapat ditinjau, diubah dan disesuaikan dengan kondisi yang berkembang". Selanjutnya dalam ayat (3) dinyatakan "Perubahan upah sebagaimana tersebut ayat (2) ditetapkan dengan Keputusan Gubernur Kepala Daerah Tingkat I Bali. Namun perubahan upah tersebut dalam tataran empiris belum pernah dilakukan hingga kini.

Dinas Kebudayaan merupakan struktur hukum yang bertanggung jawab atas pelaksanaan Keputusan Gubernur Kepala Daerah Tingkat I Bali Nomor 394 Tahun 1997. Dalam melaksanakan Keputusan Gubernur Kepala Daerah Tingkat I Bali Nomor 394 Tahun 1997, Dinas Kebudayaan sebagaimana yang diterangkan oleh Ni Wayan Sulatriani telah melakukan berbagai upaya. Upaya tersebut dilakukan dengan mengadakan rapat koordinasi antara instansi terkait di lingkungan provinsi Bali, para pelaku kesenian pertunjukan (sanggar/ sekaa) dan pihak yang menggunakan jasa kesenian pertunjukan yakni General Manager Hotel dan Restoran. Dalam rapat yang dilaksanakan pada tanggal 31 Januari 2002 tersebut dibahas mengenai masalah pengupahan (wawancara pada 3 April 2012).

Dinas Kebudayaan Provinsi Bali sebagaimana yang diterangkan oleh $\mathrm{Ni}$ Wayan Sulatriani telah berupaya dalam memperjuangkan upah yang diterima sekaa/ organisasi kesenian agar sesuai dengan standardisasi yang ditetapkan dalam Keputusan Gubernur Kepala Daerah Tingkat I Bali Nomor 394 Tahun 1997 (wawancara pada 3 April 2012). Namun, perjuangan tersebut tidak dilakukan secara terus-menerus. Kewajiban kepemilikan surat ijin bagi sekaa/ organisasi kesenian yang akan melakukan pertunjukan pariwisata membuat Dinas Kebudayan Provinsi Bali sebagaimana yang diterangkan oleh Ni Wayan Sulatriani juga aktif dalam menyurati Pemerintah Kabupaten dan Kota se-Bali untuk mengimbau sekaa atau 
sanggar seni pertunjukan pariwisata agar mencari surat ijin pertunjukan pariwisata yang dikeluarkan oleh Gubernur melalui Dinas Kebudayaan. Dinas Kebudayaan telah melakukan sosialisasi Keputusan Gubernur Kepala Daerah Tingkat I Bali Nomor 394 Tahun 1997 kepada sekaa. Sosialisasi tersebut dilakukan bersama-sama oleh Tim Teknis Kesenian Daerah yang keanggotaannya terdiri dari Dinas Kebudayaanm, Dinas Pariwisata Daerah, Biro Hukum, ISI Denpasar dan Listibya Provinsi Bali. Sosialisasi pernah dilakukan pada tahun 1997, 1998 dan 2002. (wawancara pada 3 April 2012).

Surat ijin yang menjadi syarat dalam melaksanakan pertunjukan pariwisata tidak dimiliki oleh sekaa/ organisasi kesenian yang melaksanakan pertunjukan tersebut. Hal ini disebabkan karena berdasarkan pengakuan sekaal organisasis kesenian, Dinas Kebudayaan tidak pernah melakukan sidak kepada mereka. Bahkan karena kelonggaran ini, sekaa/ organisasi kesenian yang telah memiliki surat ijin pertunjukan tidak memperpanjang sampai masa berlakunya habis. Padahal sekaa/ organisasi kesenian memiliki kewajiban untuk memperpanjang surat ijin setiap tiga tahun sekali. Sekaa/ organisasi kesenian yang pernah memiliki surat ijin pertunjukan merasa tidak ada manfaat yang dirasakan sejak memiliki surat ijin.

Substansi Keputusan Gubernur Kepala Daerah Tingkat I Bali Nomor 394 Tahun 1997 sesungguhnya mengandung beberapa poin pokok yang harus disosialisasikan, namun sosialisasi hanya difokuskan pada penerbitan surat ijin pertunjukan saja. Padahal ada beberapa hal substansial yang penting seperti tempat pementasan dan berhias yang layak, konsumsi, transportasi, jaminan sosial (jasa raharja dan kesehatan) serta standar pengupahan bagi sekaa/ organisasi kesenian. Sosialisasi ini sangat penting untuk dilakukan karena tujuan penting dari pengembangan industri pariwisata adalah peningkatan kesejahteraan masyarakat, terutamanya yang bergerak di industri pariwisata itu sendiri.

Sosialisasi dan pembinaan yang tidak dilakukan secara berkala disebabkan karena program ini tidak dilaksanakan setiap tahun tahun sehingga apabila tidak diprogramkan maka tidak akan ada anggaran untuk kegiatan sosialisasi dan 
pembinaan terhadap sekaal organisasi kesenian sehubungan dengan Keputusan Gubernur Kepala Daerah Tingkat I Bali Nomor 394 Tahun 1997.

Budaya hukum yang ada dalam masyarakat sangat dipengaruhi oleh agama, posisi seseorang dalam masyarakat, kepentingan seseorang bahkan juga faktor-faktor karier. ${ }^{4}$ Lemahnya efektivitas Keputusan Gubernur Kepala Daerah Tingkat I Bali Nomor 394 Tahun 1997 disebabkan karena budaya masyarakat secara umum. Budaya hukum masyarakat secara umum masih menganggap bahwa kesenian daerah sebagai kegiatan yang dilakukan oleh golongan ekonomi menengah ke bawah. Masyarakat menganggap sebagai suatu hal yang biasa jika seniman Bali yang akan pentas menaiki alat angkutan truck atau colt. Bahkan berpapasan dengan seniman menjadi suatu keistimewaan tersendiri bagi masyarakat. Masyarakat sering menyapa seniman yang kebetulan berpapasan jalan dengannya. Kesenian sendiri belum dianggap sebagai aset dalam pembangunan pariwisata budaya. Pertunjukan kesenian terutama yang dilakukan di hotel dan restoran cenderung dianggap sebagai pelengkap.

Pertunjukan sering diposisikan sebagai suatu pelengkap acara, biasanya makan malam di hotel/restoran. Secara umum, penghargaan masyarakat akan kesenian Bali masih sangat minim. Mereka masih mengeluh dan mencoba untuk menawar jika harus membayar sebesar Rp 50.000,00 untuk setiap pertunjukan kesenian yang ditonton di panggung-panggung kesenian. Padahal jika diperhatikan harga tiket tersebut sangat murah, apalagi bagi pertunjukan seni yang melibatkan banyak seniman dengan pakaian dan make up yang tidak sederhana. Hal tersebut sangat berbeda pada pertunjukan seni yang diadakan oleh para artis nasional maupun internasional. Masyarakat tidak mempermasalahkan jika mereka harus membayar hingga jutaan rupiah dan rela menunggu antrean tiket demi sebuah pertunjukan.

Pemakai jasa baik pihak hotel, restoran maupun panggung pertunjukan, tidak memandang bahwa Keputusan Gubernur Kepala Daerah Tingkat I Bali Nomor 394 Tahun 1997 sebagai sesuatu yang harus dilaksanakan. Dasar dari hubungan kerja

\footnotetext{
${ }^{4}$ H. Heri Tahir. 2010. Proses Hukum yang Adil Dalam Sistem Peradilan Pidana di Indonesia. Yogyakarta:, Laksbang, h. 156.
} 
mereka dengan sekaa/ organisasi kesenian adalah kesepakatan upah. Jika sekaa/ organisasi kesenian menerima upah maka pertunjukan dilaksankan. Pemakai jasa tidak mau dipusingkan dengan permasalahan sarana dan fasilitas, konsumsi, jaminan sosial ataupun surat ijin pertunjukan. Konsep ini memang sejalan dengan dunia bisnis yang menginginkan segalanya serba cepat dan praktis.

Penampilan pertunjukan kesenian dalam suatu acara di hotel dan restoran memang hanya dipandang sebagai pelengkap. Karena sifatnya sebagai pelengkap maka pemakai jasa tidak merencakan bangunannya (hotel atau restoran) untuk membangun tempat yang layak untuk berhias bagi para anggota sekaa/ organisasi kesenian yang menyelenggarakan pertunjukan. Pemakai jasa juga menganggap bahwa upah yang diberikan sudah cukup sehingga mereka tidak perlu lagi dibebani dengan penyediaan konsumsi. Apalagi pertunjukan hanya dilakukan dalam hitungan menit atau paling lama 2 jam. Mereka juga menghemat sumber daya untuk mengurusi seniman yang tampil di acaranya.

Pemberian jaminan sosial juga bukan menjadi fokus yang harus diberikan oleh pemakai jasa, karena pertunjukan hanya dilakukan secara insidental. Kalaupun pertunjukan dilakukan secara berkala maka pemakai jasa tidak memandang bahwa seniman yang tergabung dalam sekaal organisasi kesenian tersebut sebagai karyawannya. Sehingga atas dasar inilah pihak pemakai jasa tidak memberikan perlindungan jaminan sosial baik itu jasa raharja maupun kesehatan sebagaimana yang diamanatkan dalam Keputusan Gubernur Kepala Daerah Tingkat I Bali Nomor 394 Tahun 1997.

Dalam Pasal 11 Keputusan Gubernur Kepala Daerah Tingkat I Bali Nomor 394 Tahun 1997 juga diatur masalah kewajiban pemilik/ pengelola yang dipergunakan sebagai tempat penyelenggaraan pertunjukan kesenian daerah untuk mengurus keberangkatan dan mengembalikan seniman yang melakukan pertunjukan kesenian daerah. Kewajiban ini tentu sangat merepotkan pihak pemakai jasa terutama pemakai jasa yang bidang usaha utamanya bukan menampilkan pertunjukan pariwisata seperti poengusaha hotel dan restoran. Pertunjukan kesenian Bali di hotel dan restoran hanyalah bersifat hiburan, sedangkan produk yang dijual adalah jasa 
akomodasi dan produk makanan serta minuman. Dari segi ekonomi, kewajiban pemakai jasa untuk memberikan konsumsi dan jaminan sosial serta menyediaan transportasi tentu sangat merugikan finansial pemakai jasa tersebut.

Pemakai jasa ada pula yang mengetahui kewajiban hukum yang dimilikinya berdasarkan Keputusan Gubernur Kepala Daerah Tingkat I Bali Nomor 394 Tahun 1997 namun tidak memiliki kesadaran hukum untuk melaksanakannya. Pihak pemakai jasa mengetahui dengan baik yang kewajiban yang harus diberikan kepada sekaa/ organisasi kesenian, namun sengaja untuk tidak melaksanakannya karena lemahnya penegakan hukum terhadap pelanggaran Keputusan Gubernur Kepala Daerah Tingkat I Bali Nomor 394 Tahun 1997. Bahkan dalam Keputusan Gubernur itu sendiri tidak diatur mengenai sanksi bagi pihak pemakai jasa yang melanggar ketentuan tersebut. Karena tidak ada unsur paksaan maka pemakai jasa tidak mau menaati aturan tersebut sepanjang pihak sekaal organisasi kesenian yang bekerjasama dengannya sepakat atas hubungan kerja, hak serta kewajiban yang ditawarkan.

Budaya hukum seniman Bali juga sangat mempengaruhi kualitas pelaksanaan Keputusan Gubernur Kepala Daerah Tingkat I Bali Nomor 394 Tahun 1997. Orang Bali pada umumnya memiliki budaya ngayah yakni bekerja secara sukarela tanpa mengharapkan atau menentukan bayaran. Budaya ini sedemikian kental dalam kehidupan masyarakat Bali. Budaya inilah yang cenderung melemahkan perlindungan hukum bagi seniman Bali. Petunjukan seni dipandang sebagai kepuasan batin dan persembahan untuk tamu yang hadir. Dengan semangat ngayah, para seniman ini tidak terlalu mementingkan imbalan yang diperoleh atas pekerjaan yang dilakukannya. Asalkan bisa melakukan pertunjukan di hotel, restoran atau panggung pertunjukan mereka sudah merasa senang. Bahkan ada kebanggaan tersendiri ketika mereka bisa bertandang ke hotel.

Kemampuan manajerial dari sekaa/ organisasi kesenian masih belum dapat dikatakan baik, akibatnya mereka tidak memiliki posisi tawar dalam menentukan upah. Persaingan antara sekaa/ organisasi kesenian yang melaksanakan kegiatan pertunjukan pariwisata ini membuat mereka menurunkan harga. Adanya salah satu 
sekaa/ organisasi kesenian yang mau dibayar dengan upah yang di bawah standar akan merusak "pasar."

Sekaa/ organisasi kesenian juga beranggapan bahwa merekalah yang membutuhkan pemakai jasa. Dalam hubungan kerja yang bersifat vertikal ini maka pemakai jasa dapat dengan leluasa menentukan upah. Jika sekaa/ organisasi kesenian ini tidak menyetujui upah yang disodorkan oleh pemakai jasa, maka pemakai jasa dapat menghubungi dan menggunakan jasa kesenian dari sekaa/ organisasi kesenian lain. Kondisi tersebut juga didukung oleh sekaa/ organisasi kesenian yang memiliki kualitas penampilan yang rata-rata. Jika mereka telah memiliki "nama" dan kualitasnya memang diakui bagus maka mereka memiliki posisi tawar yang lebih tinggi.

Lemahnya efektivitas dari Keputusan Gubernur Kepala Daerah Tingkat I Bali Nomor 394 Tahun 1997 juga disebabkan karena rendahnya pengetahuan hukum dari seniman yang tergabung dalam sekaa/ organisasi kesenian. Mereka bahkan tidak mengetahui adanya Keputusan Gubernur Kepala Daerah Tingkat I Bali Nomor 394 Tahun 1997. Sekaa/ organisasi kesenian ini tidak mengetahui hak dan kewajiban sehingga mereka tidak mampu melindungi diri dan memperjuangkan hak-haknya.

Ketidakefektivan Keputusan Gubernur Kepala Daerah Tingkat I Bali Nomor 394 Tahun 1997 yang mengatur mengenai perijinan disebabkan karena sekaa/ organisasi kesenian tidak merasakan manfaat setelah memiliki surat ijin pertunjukan. Hal ini menyebabkan sekaa/ organisasi kesenian yang pernah memiliki ijin tidak memperpanjang ijinnya kembali. Mereka juga merasakan longgarnya penegakan Keputusan Gubernur Kepala Daerah Tingkat I Bali Nomor 394 Tahun 1997. Sekaa/ organisasi kesenian yang tidak memiliki ijin tidak dijatuhkan sanksi. Terhadap sekaa/ organisasi kesenian yang memiliki ijin pun tidak pernah dilaksanakan sidak. Sehingga surat ijin dipandang tidak ada gunanya.

Awalnya sekaa/ organisasi kesenian mengharapkan bahwa setelah mereka memiliki ijin pertunjukan maka mereka dapat dilindungi oleh pemerintah, terutama dalam memperjuangkan upah. Namun kenyataannya, pihak pemakai jasa tidak pernah mempertanyakan keberadaan surat ijin tersebut dan tidak membedakan 
perlakuan antara sekaa/ organisasi kesenian yang memiliki surat ijin pertunjukan dengan yang tidak memiliki surat ijin pertunjukan.

Lemahnya efektivitas Keputusan Gubernur Kepala Daerah Tingkat I Bali Nomor 394 Tahun 1997 tidak semuanya disebabkan karena Sekaal organisasi kesenian tidak memiliki pengetahuan hukum. Ada sejumlah ketentuan yang memang mereka ketahui namun tidak mampu melaksanakannya. Contohnya, mereka mengetahui bahwa ada larangan dalam penggunaan truk sebagai alat transportasi bagi penari/ penabuh sebagaimana yag diatur dalam Pasal 10 b Keputusan Gubernur Kepala Daerah Tingkat I Bali Nomor 394 Tahun 1997, namun mereka tetap menggunakan truck karena minimnya upah yang diterima oleh sekaa/ organisasi kesenian tersebut.

Sekaa/ organisasi kesenian tidak memperjuangkan hak-haknya bukan karena tidak mengetahui hak-haknya, namun karena malu memperjuangkan hak-haknya. Mereka mengetahui bahwa dalam setiap pementasan mereka memiliki hak untuk mendapatkan konsumsi, namun apabila pihak pemakai jasa tidak memberikannya, maka mereka tidak akan menuntut karena malu untuk melakukan hal tersebut. Sehingga sekaa/ organisasi kesenian ini hanya menunggu kesadaran dari pemakai jasa untuk melaksanakan kewajibannya.

Dalam ketentuan Pasal 6 Keputusan Gubernur Kepala Daerah Tingkat I Bali Nomor 394 Tahun 1997 disebutkan bahwa setiap pemegang wajib menjadi asosiasi kesenian yang diakui oleh Pemerintah Daerah. Pemegang yang dimaksud disini adalah sekaa/ organisasi kesenian yang telah memiliki ijin pertunjukan. Namun ketentuan ini tidak serta merta dapat terlaksana karena sekaa/ organisasi kesenian ini tidak mampu melakukan koordinasi dengan sekaa/ organisasi kesenian lainnya. Bahkan ada pandangan bahwa sekaa/ organisasi kesenian lain adalah saingan.

Sarana dan fasilitas adalah faktor fisik yang sangat penting dalam menentukan efektivitas hukum. Fasilitas atau sarana amat penting untuk mengefektifkan suatu aturan tertentu. Ruang lingkup sarana dimaksud, terutama sarana fisik yang berfungsi 
sebagai faktor pendukung. ${ }^{5}$ Dalam Keputusan Gubernur Kepala Daerah Tingkat I Bali Nomor 394 Tahun 1997 ditemukan beberapa sarana dan fasilitas yang menentukan efektivitas aturan tersebut. Adapun sarana dan fasilitas tersebut meliputi sarana dan fasilitas dalam mencari ijin pertunjukan, tempat pertunjukan, tempat berhias, alat transportasi dan alat-alat musik tradisional yang digunakan dalam pertunjukan.

Dalam proses penerbitan ijin pertunjukan maka Tim Teknis melakukan penelitian dan penilaian terhadap kualitas kesenian yang ditampilkan oleh sekaa/ organisasi kesenian. Dalam penilaian tersebut, Tim Teknis atau Dinas Kebudayaan tidak memberikan menyediakan kostum, panggung atau make up bagi penari, akibatnya pihak sekaa. organisasi kesenian merasa terbebani dengan secara finansial dalam kegiatan penilaian tersebut. Mereka dengan upah yang minim harus mengeluarkan uang untuk mempersiapkan penampilan saat penilaian tersebut.

Tempat pertunjukan umumnya dapat dikatakan layak karena pihak pemakai jasa memang sudah mempersiapkan tempat tersebut dalam kegiatan usaha yang dijalankannya. Bahkan tempat pertunjukan menjadi media untuk menarik pengunjung. Namun tempat berhias umumnya belum layak. Sekaa/ organisasi kesenian hingga harus berhias di kebun karena tidak adanya tempat khusus yang disediakan oleh pemakai jasa. Pemakai jasa juga tidak menyediakan kostum dan alat make up.

Pemakai jasa berdasarkan ketentuan dalam Keputusan Gubernur Kepala Daerah Tingkat I Bali Nomor 394 Tahun 1997 berkewajiban untuk mengatur alat transportasi atau memberikan biaya tambahan untuk transportasi. Namun biasanya alat transportasi disediakan sendiri oleh sekaal organisasi kesenian. Hal ini disebabkan karena pemakai jasa tidak memiliki sarana transportasi bagi sekaa/ organisasi kesenian yang pentas di tempatnya. Sekaa/ organisasi kesenian juga sering mengunakan truck sebagai alat transportasi bagi seniman karena pihak mereka tidak mampu menggunakan kendaraan biasa. Penggunaan alat musik tradisional yakni gamelan diwajibkan dalam pertunjukan kesenian kecuali jika pertunjukan

\footnotetext{
${ }^{5}$ H. Zainuddin Ali. 2010. Filsafat Hukum, Jakarta: Sinar Grafika, h. 96.
} 
tersebut dilakukan untuk kepentingan seminar, ceramah dan sejenisnya. Dalam kegiatan seminar, ceramah dan sejenisnya dapat digunakan iringan musik dari hasil rekaman.

Minimnya sarana dan fasilitas dalam menjamin efektivitas Keputusan Gubernur Kepala Daerah Tingkat I Bali Nomor 394 Tahun 1997 juga dirasakan oleh Dinas Kebudayaan Provinsi Bali selaku struktur hukum. Dinas Kebudayaan tidak memiliki sarana dan fasilitas yang cukup untuk melaksanakan upaya preventif dan upaya represif terhadap penegakan Keputusan Gubernur Kepala Daerah Tingkat I Bali Nomor 394 Tahun 1997. Hal ini terkait dengan minimnya atau bahkan tidak adanya dana operasional yang disediakan untuk penegakan Keputusan Gubernur Kepala Daerah Tingkat I Bali Nomor 394 Tahun 1997.

\section{UPAYA-UPAYA PEMERINTAH PROVINSI BALI UNTUK MELINDUNGI SEKAA/ ORGANISASI KESENIAN}

Keputusan Gubernur Kepala Daerah Tingkat I Bali Nomor 394 Tahun 1997 belum efektif dalam meningkatkan mutu dan kualitas kesenian dan derajat hidup seniman Bali. Hal tersebut terlihat dari sejumlah fakta empiris yang telah diuraikan pada bab sebelumnya. Gubernur Bali Made Mangku Pastika mengatakan pemerintah sangat tidak rela jika seniman Bali masih mendapatkan perlakuan yang tidak layak seperti upah yang minim, alat penjemputan yang masih seadanya, tempat ganti yang kurang memadai. Apalagi jika ada seniman yang diangkut dengan menggunakan truk. Kondisi ini membutuhkan upaya-upaya dari Pemerintah Provinsi Bali dalam meningkatkan kesejahteraan dan derajat seniman Bali. Upaya tersebut meliputi upaya preventif dan upaya represif.

Upaya preventif adalah upaya yang dilakukan untuk mencegah terjadinya suatu penyimpangan sosial. Penyimpangan sosial yang dimaksudkan adalah pelanggaran terhadap Keputusan Gubernur Kepala Daerah Tingkat I Bali Nomor 394 Tahun 1997. Upaya preventif yang dapat dilakukan oleh Dinas Kebudayaan dalam mencegah pelanggaran terhadap Keputusan Gubernur Kepala Daerah Tingkat I Bali Nomor 394 Tahun 1997 adalah dengan: 
a. Mendata sekaa/ organisasi kesenian serta hotel, restoran atau pengguna jasa kesenian yang melaksanakan pertunjukan kesenian.

b. Mendatangi dan membantu pengurusan ijin pertunjukan bagi sekaa/ organisasi kesenian yang tidak memiliki ijin atau pernah memiliki ijin namun tidak memperpanjang ijin sampai jangka berlaku habis.

c. Melakukan sosialisasi terhadap Keputusan Gubernur Kepala Daerah Tingkat I Bali Nomor 394 Tahun 1997 baik bagi sekaa/ organisasi kesenian maupun hotel, restoran atau pengguna jasa kesenian lainnya.

d. Melakukan pembinaan terhadap sekaa/ organisasi kesenian serta hotel, restoran atau pengguna jasa kesenian.

e. Memprakarsasi dan mengkoordinasikan pembentukan asosiasi kesenian yang terdiri dari sekaa/ organisasi kesenian yang melaksanakan kegiatan pertunjukan pariwisata.

f. Menjembatani pertemuan antara sekaa/ organisasi kesenian dengan hotel, restoran atau pengguna jasa kesenian.

g. Melakukan sosialisasi Keputusan Gubernur Kepala Daerah Tingkat I Bali Nomor 394 Tahun 1997 di media massa

h. Melaporkan temuan di lapangan sehubungan dengan penegakan Keputusan Gubernur Kepala Daerah Tingkat I Bali Nomor 394 Tahun 1997.

i. Membentuk dan melaksanakan kebijakan-kebijakan lain yang dapat mendukung terlaksananya Keputusan Gubernur Kepala Daerah Tingkat I Bali Nomor 394 Tahun 1997.

Upaya represif dapat dilakukan melalui penegakan hukum. Penegakan hukum pada hakikatnya merupakan penerapan diskresi (kebijakan) yang membuat keputusan hukum tidak secara ketat diatur undang-undang melainkan juga berdasarkan kebijaksanaan antara hukum dan etika. ${ }^{6}$ Penegakan hukum adalah sebuah tugas. Tuas

\footnotetext{
${ }^{6}$ Satjipto Rahardjo. 1995. Masalah Penegakan Hukum. Bandung: Alumni, h. 80.
} 
yang diemban oleh aparat penegak hukum, dan karena tugas maka seperti dikatakan Kant, merupakan "kewajiban kategoris", "kewajiban mutlak". Di sini tidak mengenal istilah "dengan syarat". Tugas adalah tugas, wajib dilaksanakan. ${ }^{7}$ Abdulkadir Muhammad mengungkapkan bahwa "penegakan hukum dapat dirumuskan sebagai usaha melaksanakan hukum sebagaimana mestinya dan jika terjadi pelanggaran memulihkan hukum yang dilanggar itu supaya ditegakkan kembali." Ada empat norma penting dalam penegakan hukum yaitu kemanusiaan, keadilan, kepatutan dan kejujuran. ${ }^{8}$ Penegakan hukum bukan hanya pada ranah dogmatig hukum namun juga pada ranah filosofi.

Kualitas penegakan hukum yang dituntut masyarakat saat ini bukan sekadar kualitas formal, tetapi terutama kualitas penegakan hukum secara material/ substansial. Kualitas substantif jelas lebih menekankan pada aspek immateriil/ non fisik dari pembangunan masyarakat/ nasional. Pembangunan nasional tidak hanya bertujuan meningkatkan kualitas masyarakat (lingkungan hidup dan kehidupan) secara materiil, tetapi juga secara immateriil. Penegakan hukum pada hakikatnya merupakan bagian integral dari upaya membangun dan meningkatkan kualitas lingkungan hidup yang lebih berbudaya dan bermakna. ${ }^{9}$

Penyimpangan dalam penegakan hukum yang tidak mendasar sama sekali (penyimpangan negatif), akan nampak sebagai penegakan hukum yang bersifat represif. Akan tetapi dapat saja terjadi penyimpangan penegakan hukum dalam rangka untuk mencapai tujuan hukum yang didasari kepentingan umum, merupakan usaha menciptakan kesejahteraan masyarakat (social welfare) sehingga dalam penegakan hukum dapat saja terjadi sebagai actual enforcement yang tidak dapat

7 Bernard L. Tanya. 2011. Penegakan Hukum Dalam Terang Etika. Yogyakarta: Genta Publishing, h.. 25.

${ }^{8}$ Abdulkadir Muhammad. 2006. Etika Profesi Hukum. Bandung: Citra aditya Bakti, h. 115.

${ }^{9}$ Barda Nawawi Arief. 2008. Masalah Penegakan Hukum dan Kebijakan Hukum Pidana Dalam Penanggulangan Kejahatan. Jakarta: Kencana Prenada Media Group, h. 19-20. 
dihindari. Namun demikian actual enforcement dalam hal ini dilakukan semata-mata untuk mengisi kekosongan hukum yang ada. ${ }^{10}$

Penegakan hukum terhadap pelanggaran Keputusan Gubernur Kepala Daerah Tingkat I Bali Nomor 394 Tahun 1997 dilakukan berdasarkan ketentuan dalam Pasal 17 Keputusan Gubernur Kepala Daerah Tingkat I Bali Nomor 394 Tahun 1997 yang menyebutkan:

(1) Ijin pertunjukan kesenian daerah ini dapat dicabut apabila:

a. tidak memenuhi ketentuan persyaratan penyelenggaraan pertunjukan kesenian daerah sebagaimana telah ditetapkan dalam Keputusan ini.

b. melakukan penyimpangan pengusahaan pertunjukan kesenian daerah.

c. melakukan pelanggaran atau penyimpangan kegiatan pertunjukan kesenian daerah yang telah mendapatkan persetujuan Gubernur Kepala Daerah.

(2) Penindakan terhadap sekaal organisasi kesenian yang melakukan penyimpangan dengan langkah-langkah sebagai berikut:

a. Peringatan lisan.

b. Peringatan tertulis.

c. Pencabutan ijin.

Berdasarkan ketentuan dalam Pasal 17 Keputusan Gubernur Kepala Daerah Tingkat I Bali Nomor 394 Tahun 1997 maka sanksi yang dapat dijatuhkan adalah sanksi administrasi. Dalam ayat (1) Pasal ini dinyatakan bahwa sanksi dapat dijatuhkan setiap pihak yang melanggar tidak memenuhi ketentuan persyaratan penyelenggaraan pertunjukan kesenian daerah sebagaimana telah ditetapkan dalam Keputusan ini, melakukan penyimpangan pengusahaan pertunjukan kesenian daerah dan melakukan pelanggaran atau penyimpangan kegiatan pertunjukan kesenian daerah yang telah mendapatkan persetujuan Gubernur Kepala Daerah. Namun jika dilihat dalam ayat (2) maka sanksi hanya dapat dijatuhkan bagi sekaa/organisasi kesenian. Sanksi tersebut berupa peringatan lisan, peringatan tertulisan dan pecabutan ijin.

Penggunaan hukum sebagai instrumen represif tidak lepas dari karakter hukum itu sendiri. Hukum adalah alat bagi manusia. Ia merupakan instrumen untuk

${ }^{10}$ Sunarto, Alternatif Meminimalisasi Pelanggaran HAM Dalam Penegakan Hukum Pidana, dalam Muladi (ed). 2009. Hak Asasi Manusia Hakekat, Konsep dan Implikasinya Dalam Perspektif Hukum dan Masyarakat. Bandung: Refika Aditama, h. 140. 
melayani kebutuhan manusia. Dalam makna ini, isolasi sistem hukum dari berbagai institusi sosial di sekitarnya justru berdampak buruk dari sisi kebutuhan manusia itu sendiri. Hukum dengan mudah berubah menjadi institusi yang melayani diri sendiri, bukan lagi melayani manusia. Hukum tidak lagi bisa diandalkan sebagai alat perubahan dan sebagai alat untuk menciptakan keadilan substantif. ${ }^{11}$ Namun masa berlakunya hukum ada batas waktunya, apalagi tentang peraturan teknis yang berkaitan dengan pengupahan dimana hukum berpacu dengan kondisi ekonomi masyarakat yang sedemikian kompleks dan mudah berubah.

Penegakan Keputusan Gubernur Kepala Daerah Tingkat I Bali Nomor 394 Tahun 1997 dapat dilakukan melalui pengawasan dan penjatuhan sanksi secara efektif terhadap setiap pelanggarannya. Salah satu penyebab tidak efektifnya Keputusan Gubernur Kepala Daerah Tingkat I Bali Nomor 394 Tahun 1997 adalah karena Dinas Kebudayaan tidak pernah menjatuhkan sanksi bagi sekaa/ organisasi kesenian tidak memiliki ijin pertunjukan dan kepada yang melanggar Keputusan Gubernur Kepala Daerah Tingkat I Bali Nomor 394 Tahun 1997. Membandingkan dengan hukum adat Bali, sanksi merupakan sarana untuk mengembalikan keseimbangan. Penjatuhan sanksi sangat perlu dilakukan untuk keseimbangan.

Upaya preventif dan upaya represif yang dilakukan oleh Pemerintah Provinsi Bali bertujuan untuk mencapai tujuan sebagaimana yang dirumuskan dalam Keputusan Gubernur Kepala Daerah Tingkat I Bali Nomor 394 Tahun 1997. Pelaksanaan upaya preventif dan upaya represif yang dilakukan oleh Dinas Kebudayaan Provinsi Bali bertujuan untuk mewujudkan Morksartham jagadhita ya ca iti dharmah (kesejahteraan jasmani dan ketenteraman batin). Dengan demikian efektivitas Keputusan Gubernur Kepala Daerah Tingkat I Bali Nomor 394 Tahun 1997 sejalan dengan perwujudan Morksartham jagadhita ya ca iti dharmah (kesejahteraan jasmani dan ketenteraman batin).

${ }^{11}$ Bernard L. Tanya, Yoan N. Simanjuntak dan Markus Y. Hage. 2010. Teori Hukum Strategi Tertib Manusia Lintas Ruang dan Generasi, Yogyakarta, Genta Publishing, h. 204. 


\section{SIMPULAN DAN SARAN}

Faktor-faktor yang mempengaruhi implementasi Keputusan Gubernur Kepala Daerah Tingkat I Bali Nomor 394 Tahun 1997 adalah faktor substansi hukum, struktur hukum, budaya hukum dan sarana serta fasilitas. Upaya-upaya Pemerintah Provinsi Bali untuk meningkatkan efektivitas pelaksanaan Keputusan Gubernur Kepala Daerah Tingkat I Bali Nomor 394 Tahun 1997 tentang Pengaturan Kesenian Daerah di Provinsi Daerah Tingkat I Bali adalah dengan upaya preventif dan upaya represif.

Gubernur hendaknya perlu segera mengamandemen Keputusan Gubernur Kepala Daerah Tingkat I Bali Nomor 394 Tahun 1997 dengan memuat ketentuan yang lebih komprehensif dan menggunakan bahasa hukum yang tepat. Amandemen terpenting adalah dengan mengatur kewajiban pemakai jasa, meningkatkan tarif pertunjukan dan mencantumkan sanksi bagi pemakai jasa. Bentuk hukum yang sebaiknya digunakan adalah Peraturan Daerah agar dapat memuat sanksi pidana bagi pelanggarnya. Pihak pemakai jasa juga perlu meningkatkan kesadaran hukum untuk melaksanakan kewajibannya. Diperlukan pula pendidikan hukum bagi sekaal organisasi kesenian untuk mengetahui dan untuk dapat memperjuangkan hak-haknya melalui saluran dan mekanisme yang benar. Dinas Kebudayaan Provinsi Bali hendaknya lebih proaktif dalam melakukan upaya preventif dan upaya represif dalam menegakkan Keputusan Gubernur Kepala Daerah Tingkat I Bali Nomor 394 Tahun 1997. Sosialisasi dan pembinaan perlu dilakukan dengan metode jemput bola. Pengawasan perlu dilakukan secara berkala. Upaya represif harus dilakukan secara konsisten. Dinas Kebudayaan perlu mengusulkan anggaran secara berkala di setiap tahunnya untuk kegiatan pengaturan kesenian dan benar-benar melaksanakan kegiatan itu dengan baik. 


\section{DAFTAR PUSTAKA}

\section{BUKU}

Abdulkadir Muhammad. 2006. Etika Profesi Hukum. Bandung: Citra aditya Bakti.

Bambang Sunggono. 2009, Metodologi Penelitian Hukum. Jakarta: Rajawali Pers.

Barda Nawawi Arief. 2008. Masalah Penegakan Hukum dan Kebijakan Hukum Pidana Dalam Penanggulangan Kejahatan. Jakarta: Kencana Prenada Media Group.

Bernard L. Tanya, Yoan N. Simanjuntak dan Markus Y. Hage. 2010. Teori Hukum Strategi Tertib Manusia Lintas Ruang dan Generasi, Yogyakarta, Genta Publishing.

Bernard L. Tanya. 2011. Penegakan Hukum Dalam Terang Etika. Yogyakarta: Genta Publishing.

Heri Tahir, H. 2010. Proses Hukum yang Adil Dalam Sistem Peradilan Pidana di Indonesia. Yogyakarta: Laksbang.

Saifullah. 2007, Refleksi Sosiologi Hukum, Bandung: PT Refika Aditama.

Satjipto Rahardjo. 1995. Masalah Penegakan Hukum. Bandung: Alumni.

Soerjono Soekanto dan Sri Mamudji, 1986. Penelitian Hukum Normatif Suatu Tinjauan Singkat. Jakarta: CV. Rajawali.

Sunarto, Alternatif Meminimalisasi Pelanggaran HAM Dalam Penegakan Hukum Pidana, dalam Muladi (ed). 2009. Hak Asasi Manusia Hakekat, Konsep dan Implikasinya Dalam Perspektif Hukum dan Masyarakat. Bandung: Refika Aditama.

Zainuddin Ali, H. 2010. Filsafat Hukum, Jakarta: Sinar Grafika.

\section{SUMBER HUKUM}

Peraturan Daerah Nomor 3 Tahun 1991 tentang Pariwisata Budaya.

Keputusan Gubernur Kepala Daerah Tingkat I Bali Nomor 394 Tahun 1997 tentang Pengaturan Kesenian Daerah di Propinsi Daerah Tingkat I Bali. 